\title{
THE IMPACT OF SOCIAL MEDIA ON LUXURY CONSUMPTION
}

\author{
Merve Çelik \\ İstanbul Kültür University, Faculty of Art and Design, İstanbul \\ m.celik@iku.edu.tr
}

\begin{abstract}
The main purpose of this search, to examine the effects of social media on luxury consumption. Online survey form created for the purpose, between the dates of 1-6 June 2016 social media has been applied to the 208 user. The Program SPSS 22.0 statistics of the survey data is realized through the evaluation of the achieved. Impact of social media on luxury consumption in determining the level of the participants, the average and standard deviation statistics were used, descriptive characteristics of the participants to examine the effects of social media on luxury consumption in terms of the kruskalWallis $\mathrm{H}$ and Mann-Whitney $\mathrm{u}$ tests were used. As a result of the research, the impact of social media on a low level of participants, the effects of luxury consumption on social media sites increased with the increment of income level and it was concluded that used. The effects of social media on luxury consumption, individuals ' gender, age, educational status, and the social media sites they use most in the research that does not vary according to other results that can be reached.
\end{abstract}

Keywords: Social Media, Social Networks, Luxury, Luxury Consumption

\section{SOSYAL MEDYANIN LÜKS TÜKETIM ÜZERİNDEKİ ETKİLERİ}

\section{$\ddot{O Z Z}$}

$\mathrm{Bu}$ araştırmanın temel amacı, sosyal medyanın lüks tüketim üzerindeki etkilerini incelemektir. Amaç doğrultusunda oluşturulan çevrimiçi anket formu, 1-6 Haziran 2016 tarihleri arasında 208 sosyal medya kullanıcısına uygulanmıştır. Anketlerden ulaşılan verilerin değerlendirilmesi bilgisayar ortamında SPSS 22.0 istatistik programı aracıllı̆ıyla gerçekleştirilmiştir. Katılımcıların lüks tüketimleri üzerinde sosyal medyanın etki düzeyinin belirlenmesinde ortalama ve standart sapma istatistiklerinden, katılımcıların tanımlayıcı özellikleri açısından sosyal medyanın lüks tüketim üzerindeki etkilerini incelemek için Kruskal Wallis $H$ ve Mann Whitney $U$ testlerinden faydalanılmıştır. Araştırma sonucunda, sosyal medyanın katılımcılar üzerindeki etkisinin düşük düzeyde olduğu, sosyal medyanın lüks tüketim üzerindeki etkilerinin gelir düzeyi ve sosyal medya sitelerinde kullanılan süre artışıyla birlikte arttığı sonucuna varılmıştır. Sosyal medyanın lüks tüketim üzerindeki etkilerinin, bireylerin cinsiyetlerine, yaşlarına, eğitim durumları ve en fazla kullandıkları sosyal medya sitelerine göre farklılık göstermediği araştırmada ulaşılan diğer sonuçlardır.

Anahtar Kelimeler: Sosyal Medya, Sosyal Ağlar, Lüks, Lüks Tüketim

\section{INTRODUCTION}

Developments in the last thirty years, as a result of technological advances, the Internet has integrated into the economic and social life of individuals. In the previous period, the individuals, who reaches the internet with computers and limited access opportunities, have become online in line with the developments in communication technologies twenty-four hours. Especially, with access of smart phones into the daily lives of individuals, accessing the internet has become easier as it is the demand for the Internet has also increased.

In the first period that internet has come out, while it has been using for research purposes, then, it has been using for commercial purposes, nowadays, it has become indispensable communication area in 
people's daily life. Even housewives, who have nothing to do with that social media networks, locate their recipes, crafts, etc. to share with each other. Even on the internet groups of elementary school students, homework, Tutoring, etc. their sharings are observed. It can be said that everyone on social media has become the center of the lives of individuals.

Today, social media get out of a area, where individuals communicate with one another the food they eat, the clothes they wear demonstrated by, expressing themselves by making comments about the products they receive has evolved to an environment. Especially, sharing the pictures of restaurant visited and luxury goods have made the social media an area, which has wars of social status. "Receiving acclaim with content that symbolizes the luxury, the individual pursuing the vision to appreciate the effort and positive feedback based hedonic consumption behaviours by developing a rational for the continuation of this situation continues to show off than buying." (Sabuncuoğlu, 2015: $370)$.

To examine the effects of luxury consumption on the use of social media in this research are studied. Also the impact on individuals in terms of the defining characteristics of luxury consumption of social media is also questioned.

Research in this direction is primarily dened the concept of social media, and then the luxury consumption were studied. In the application part of the study, with a survey of social media users on social media are trying to put forward the effects on luxury consumption.

\section{SOCIAL MEDIA}

Social media is the fastest emerging technology in the context of Internet and Communication Technologies (Kang and Schuett, 2013: 93). Social media users information, giving you the opportunity to share their ideas and feelings, mutual interaction is the term used for online tools and websites that it creates (Sayimer, 2008:123). In another definition, the content created by the user and by the user to interact personally with the community to create and share content that is spread and all of the channels (Ozkasikci, 2012: 37).

From past to present, the links between the people, which are not seen in the concrete, have become more visible in the environment, which has been created on internet. Social media has changed with the proliferation of internet and today the number has reached hundreds of millions, expressed in the number of users (Korkmaz, 2013: 109). 3,419 billion in 2016 according to the results of the current research that is performed 2,307 billion people connecting to the internet and social media users are actively located.

When examining the statistics in terms of Turkey, 79.14 million of the population, 46.3 million people and 42 million active social media connecting to the internet is located on. The most used social media in Turkey, 32\% of Facebook compared with 24\% WhatsApp \%20 Facebook Messenger, with 17\% and Twitter at $16 \%$ with is Instagram http://www.dijitalajanslar.com).

Social media platforms offer individuals the possibility to share regarding their life, by allowing them to invite their friends or colleagues profiles and those profiles created, or sent by e-mail (Kaplan and Haenlein, 2010: 63). Besides, as people, who never know each other, have chance to find the people that they looked for by the keywords, they have chance to make connection with the people that they have seen each other for years. At the same time, people have possibilty to increase the level of their awareness and profile; they also have chance to see the others' connections and to message each other (Tugrul et al. 2009: 30). Ilicak Aydinalp (2013: 4), because of these characteristics that the social media environment associated with the concept of surveillance is started. In a sense, to spy on each other and everyone is enjoying it. Thus, individuals, false or real, familiar or unfamiliar with people by sharing personal satisfaction. Although a person's behavior to declare his/her horoscope or to share his/her holiday photos to another person in a concert may be evaluated as a meaningless attitude, these kinds of behaviors are so meaningful in social media environment. "A big world tolerates silly habits, ideas in social media; in fact it declares that it liked or not". 
Among the social media environments, it is observed that especially social media, photos, videos, location, notification, venue reviews, such as content sharing, Facebook, Instagram and YouTube social media environments are used for consumption purposes, such as showing off (Sabuncuoğlu, 2015: 374).

\section{LUXURY CONSUMPTION}

Although there is a consensus in the literature on a definition of the concept of luxury in daily life, on top of the standard provides the benefit, and the cost is defined as things that are high. "Luxury, individuals ' happiness, comfort, or convenience in accordance with the requirement of giving a sense of satisfaction, a perception of what is required. A rich source of luxury is superior and more rich people who look and do a comparison of within the environment, that has a better appearance than others." (Kiray, 2005: 15).

Luxury products often on the market rare and hard-to-find particularly privileged to consumers, the price is high, a prestigious high symbolic and emotional benefits to consumers and refers to products that provide meals ( $\mathrm{Li}$ and others, 2012: 1517). It is seen that the different categories of luxury products defined in the literature. Luxury products and luxury services in a classification were defined by dividing into two. In this stage, luxury goods: clothing, shoes, handbags, accessories, lingerie, perfume, Jewelry, watches, electronics and phones, household products, cars, home decor, pet products, luxury food, gifts. Luxury services, transportation, travel, restaurant dishes, plastic surgery, health and fitness, entertainment venues, accommodation services, medical care services, home services, financial services, adventure sports services, child care services, pet care services (Cornea et al. 2012: 145).

The concept of luxury, always at the summit of the pyramid of life took place, and has formed a boundary between rich and poor. Determinative factor of this limit, silk, gold, silver, precious or semiprecious stones, furs such as objects, are the objects sought by the rich and known (Zeybek, 2013: 2).

Today, each day daily life due to the expansion of consumer culture in the determination of consumption increase. Individuals with the products they consume, they almost revere. What they are, what they consume who are trying to express with consumers, satisfying the needs and requirements of, other than that you provide them with personal and economic gains to Jun for consumption, luxury consumption trend started showing more (and Ercan Aksu, 2012: 1). It can be said that luxury consumption is consumed for elevating the social status and economic benefits rather than providing show physiological individuals (Connor and Akyazgan, 2003: 23).

Consumption of luxury products and brands for their social media purposes of individuals, who sought to vanity, and luxury restaurants, sightseeing places, foods they eat, trying to convey their identity by showing their way of life to other individuals.

Consumer identities in the literature are among the topics quite interesting with the relationships between luxury products (Atwal and Williams, 2009; Perez and others, 2010; Li and others, 2012; Sabah-Kiyan, 2013). That takes place in the upper class flaunted to show themselves superior to other people and individuals considering they consume luxury products to demonstrate in the social media environment, finding space and time are (Sabuncuoğlu, 2015: 374). Thus, the upper class have been thinking of creating an identity for themselves.

\section{A RESEARCH ON SOCIAL MEDIA USERS TO DETERMINE THE IMPACT OF SOCIAL MEDIA ON LUXURY CONSUMPTION}




\subsection{Research Method}

General scanning model research have been carried out and is intended to be shown on a small sample of the current situation. In a survey to determine the impact of social media on luxury consumption data were collected by survey method. The poll in question was created by the researcher and consists of two parts. The first section of the questionnaire multiple choice questions to determine the characteristics of the 6 descriptive participants. In order to determine the effects of social media on luxury consumption in the second part 10 to a 5-point likert proposition is located. The convenience sampling method used in surveys online survey and created easy to implement was applied to 208 social media users between the dates of 1-6 June 2016.

To determine the level of reliability of the scale used in the research the "Cronbach's Alpha" reliability coefficient of the overall scale and benefit from alpha $=0.971$, respectively.

To test the validity of the scale, structural, descriptive(expander) factor analysis was conducted.Done Bartlett's test $(\mathrm{p}=0.000<0.05)$ determined that there is a relationship between the variables taken for factor analysis $(\mathrm{KMO}=0.943>0,60)$ for the implementation of factor analysis the sample size was enough.

By applying the factor analysis method, the structure of the equal relationship between the factors remain the same is provided. Factor analysis a total variance explained of variables \% 79.310 the only factor that are grouped under. Related to the reliability of Alpha according to the value of social media and explained variance of the scale is a reliable and valid tool to determine the impact on luxury consumption is understood. Factor structure of the scale can be seen below.

Table 1. Factor Loadings

\begin{tabular}{|l|c|}
\hline Propositions & Factor Loadings \\
\hline $\begin{array}{l}\text { My followers' knowledge about my luxury products is very } \\
\text { important to me. }\end{array}$ &, 912 \\
\hline $\begin{array}{l}\text { Everybody's knowledge about that I have expensive luxury } \\
\text { products is important to me. }\end{array}$ &, 908 \\
\hline $\begin{array}{l}\text { The reason of sharing the luxury products on social } \\
\text { networks relaxes me. }\end{array}$ &, 900 \\
\hline $\begin{array}{l}\text { I believe in that sharing the luxury products that I have on } \\
\text { social networks provide me privilege. }\end{array}$ &, 899 \\
\hline $\begin{array}{l}\text { The reason of sharing luxury products that I owned on } \\
\text { social networks is that I can be accepted by everybody. }\end{array}$ &, 895 \\
\hline $\begin{array}{l}\text { I enjoy sharing the luxury clothing and accessories that I } \\
\text { have on the social networks. }\end{array}$ &, 872 \\
\hline $\begin{array}{l}\text { Sharing the luxury products that I have on the social media } \\
\text { provides me social status. }\end{array}$ &, 862 \\
\hline $\begin{array}{l}\text { I am using the social media to share luxury products that I } \\
\text { have. }\end{array}$ &, 857 \\
\hline $\begin{array}{l}\text { It is important for me to reach my friends' luxury products, } \\
\text { which are showed and share on the social networks. }\end{array}$ & \begin{tabular}{l}
\hline $\begin{array}{l}\text { The reason of sharing luxury products that I owned on } \\
\text { social networks is about increasing follower count of mine. }\end{array}$ \\
\hline \multicolumn{1}{|c|}{ Alpha=0.971 }
\end{tabular} \\
\hline \multicolumn{1}{|l|}{ The total variance explained \%79.310 } \\
\hline
\end{tabular}


In research surveys that is reached as a result of the analysis of the data by means of SPSS 22.0 program were analyzed. Descriptive statistics frequency and percentage for determining the characteristics of the participants has benefited from. In determining the impact of social media on luxury consumption, average and standard deviation statistics were applied.

For the size of the scale points between 1 and 5, are evaluated. This interval has a width of 4 percentage points. This width equal to the width of five separated $1.00-1.79$ "very low", $1.80-2.59$ "low", 2.60 - 3.39 "middle", 3.40-4.19 " high, 4.20-5.00 very high between the findings were interpreted as (http://www.istatistikanaliz.com/faktor_analizi.asp)

The descriptive characteristics of the participants according to the status of luxury consumption of social media in the determination of the effect on differentiation by gender differentiation-Whitney-U test for differences in the determination of the other variables, Kruskal-Wallis test was used. KruskalWallis tests to examine the differences that emerged as complementary in the aftermath of manWhitney-u test was done. Findings the 95\% confidence interval, 5\% level has been tested at significance level.

\subsection{The Findings Of The Research}

The achieved results are given in Table 2 descriptive characteristics of respondents.

\begin{tabular}{|c|c|c|c|}
\hline Variables & Groups & $\begin{array}{l}\text { Frequency } \\
\text { (n) }\end{array}$ & Percent (\%) \\
\hline \multirow{5}{*}{ Age } & $17-21$ & 22 & 10,6 \\
\hline & $22-26$ & 50 & 24,0 \\
\hline & $27-31$ & 80 & 38,5 \\
\hline & $32-36$ & 28 & 13,5 \\
\hline & 37 and above & 28 & 13,5 \\
\hline \multirow{2}{*}{ Sex } & Female & 116 & 55,8 \\
\hline & Male & 92 & 44,2 \\
\hline \multirow{4}{*}{ Education Status } & High school & 12 & 5,8 \\
\hline & \begin{tabular}{|l|} 
University \\
\end{tabular} & 104 & 50,0 \\
\hline & \begin{tabular}{|l|} 
Post graduate \\
\end{tabular} & 68 & 32,7 \\
\hline & Doctorate & 24 & 11,5 \\
\hline \multirow{4}{*}{ Monthly Income } & $0-1300 \mathrm{TL}$ & 20 & 9,6 \\
\hline & \begin{tabular}{|l}
$1301-3300 \mathrm{TL}$ \\
\end{tabular} & 84 & 40,4 \\
\hline & \begin{tabular}{|l}
$3301-5300 \mathrm{TL}$ \\
\end{tabular} & 72 & 34,6 \\
\hline & $5301-7300 \mathrm{TL}$ & 32 & 15,4 \\
\hline \multirow{5}{*}{$\begin{array}{l}\text { Frequency Of Visiting Sites That Are } \\
\text { Actively Used }\end{array}$} & 30 minutes or less & 18 & 8,7 \\
\hline & \begin{tabular}{|l} 
Approximately 1 hour \\
\end{tabular} & 34 & 16,3 \\
\hline & 1-2 hours & 58 & 27,9 \\
\hline & 2-3 hours & 74 & 35,6 \\
\hline & 4 hours and above & 24 & 11,5 \\
\hline \multirow{5}{*}{ The Most Used Social Network } & Facebook & 42 & 20,2 \\
\hline & \begin{tabular}{|l|} 
Twitter \\
\end{tabular} & 30 & 14,4 \\
\hline & \begin{tabular}{|l|} 
Instagram \\
\end{tabular} & 88 & 42,3 \\
\hline & \begin{tabular}{|l|} 
Snapchat \\
\end{tabular} & 28 & 13,5 \\
\hline & Linkedin & 20 & 9,6 \\
\hline \multicolumn{2}{|l|}{ Total } & 208 & 100,0 \\
\hline
\end{tabular}


The study of social media users, $22 \%$ to $10.6 \%) 17-21,50 \%(\% 24,0) 22-26,80(\% 38,5) 27-31,28 \%$ $(\% 13,5) 32-36,28 \%(13.5 \%)$ and 37 years old and is located at, $116(\% 55,8$ female), $92 \%(\% 44,2)$ are male.

Of participants $12 \%$ (by 5.8\%) high school, 104\%50,0) University, 68\% (\%32,7) graduate studies, 24 (\%11,5) and doctoral level of Education 20\% (\%9,6) 0-1300 TL, 84\% (\%40,4) 1301-3300 TL, 72\% $(\% 34,6) 3301-5300 \mathrm{TL}, 32 \%(\% 15,4) 5301-7300 \mathrm{TL}$ monthly income level.

Of the respondents $18 \%$ (up $8.7 \%$ ) to visit sites that are actively used within a period of 30 minutes or less, 34 percent $(\% 16,3)$, approximately a 1 hour, $58 \%$ (\%stood at 27.9$) 1-2$ hours, $74 \%(\% 35,6) 2-3$ hours, $24(\% 11,5) 4$ hours and above are used as the sites that are visiting.

When compared to the social networks they use most of the participants $42 \%$ (\%are 20.2) Facebook, $30 \%$ to 14.4$)$ Twitter, $88 \%(\% 42,3)$ Instagram, 28\% $(\% 13,5)$ Snapchat, and $20 \%(\% 9,6)$ are using LinkedIn.

Participants accessed the data in Table 3 for the impact of social media on the luxury consumption.

Table 3. The impact of social media on luxury consumption

\begin{tabular}{|c|c|c|c|c|}
\hline $\mathbf{N}$ & Mean & Sd & Min. & Max. \\
\hline 208 & 2,112 & 1,029 & 1,000 & 4,800 \\
\hline
\end{tabular}

The data in Table 3 is examined, "the effect of social media on luxury consumption" $2,112 \pm 1,029$ level, in other words, the impact of social media on luxury consumption is low.

Research on the effects of social media in luxury consumption elsewhere is not any different according to the characteristics of the participants questioned as descriptive, taken in this direction a set of participants, their age, gender, education level, and does not vary according to the network, it was found that the most used social media.

Monthly income of respondents according to the level of status differentiation the effect of social media on luxury consumption are given in Table 4.

\begin{tabular}{|c|c|c|c|c|c|c|}
\hline Group & $\mathbf{N}$ & Mean & Sd & KW & $\mathbf{p}$ & Variance \\
\hline $0-1300 \mathrm{TL}$ & 20 & 2,160 & 0,982 & \multirow{4}{*}{22,353} & \multirow{4}{*}{0,000} & \multirow{4}{*}{$\begin{array}{l}4>1 \\
3>2 \\
4>2 \\
4>3\end{array}$} \\
\hline $1301-3300 \mathrm{TL}$ & 84 & 1,843 & 0,929 & & & \\
\hline $3301-5300 \mathrm{TL}$ & 72 & 2,108 & 1,027 & & & \\
\hline $5301-7300 \mathrm{TL}$ & 32 & 2,794 & 1,035 & & & \\
\hline
\end{tabular}


Monthly income of respondents according to their level of social media in luxury consumption status performed to examine the effects on their differentiation Kruskal-Wallis H-test significant differences were determined between the groups $((\mathrm{KW}=22,353 ; \mathrm{p}=0,000<0.05)$.

Are performed to examine the differences among the groups with Mann-Whitney u test as a result of the following data were obtained:

- Accordingly, the effect of the ones, who have 5301-7300 TL monthly income luxury consumption on social media of your monthly income level was found to be significantly higher in the lower ones.

- Monthly income monthly income the effect of social media on luxury consumption 1301-3300 TL 3301-5300 TL the ones are superior to the ones.

Participants often visit social media sites actively used social media, according to the status of luxury consumption of the effect on differentiation are given in Table 4.

Table 5. Participants are on social media sites per day according to the time differentiation of the effect of social media on luxury consumption status

\begin{tabular}{|c|c|c|c|c|c|c|}
\hline Group & $\mathbf{N}$ & Mean & Sd & KW & $\mathbf{p}$ & Variance \\
\hline 30 Minutes or Less & 18 & 1,378 & 0,665 & \multirow{5}{*}{19,596} & \multirow{5}{*}{$\mathbf{0 , 0 0 1}$} & \multirow{5}{*}{$\begin{array}{l}3>1 \\
4>1 \\
5>1 \\
4>2\end{array}$} \\
\hline Approximately 1 Hour & 34 & 1,959 & 1,108 & & & \\
\hline 1-2 Hours & 58 & 2,045 & 0,887 & & & \\
\hline 2-3 Hours & 74 & 2,332 & 0,968 & & & \\
\hline 4 hours and above & 24 & 2,358 & 1,352 & & & \\
\hline
\end{tabular}

According to the time of social media participants on social media sites per day are performed to examine their effects on differentiation in luxury consumption status, kruskal-Wallis H-test significant differences were determined between the groups $(\mathrm{KW}=19,596 ; \mathrm{p}=0.001<0.05)$.

Are performed to examine the differences among the groups with Mann-Whitney $u$ test as a result of the following data were obtained:

- The amount of time on social media sites are 1-2 hours, 2-3 hours, and 4 hours the effect of social media on luxury consumption frequency of visits and the above ones are 30 minutes or less is likely what happened.

- Those 2-3 hours are the amount of time on social media sites the effect of social media on luxury consumption is likely what happened to the frequency of visits about 1 hour.

\section{CONCLUSION}

In the context of recent technological developments, although it is new, as structured concept in people's lives, social media has found chance as an area for individuals to express themselves. In the social media, which has an increasing user numbers, individuals have chance tos hare their photos, videos, feelings and ideas with each other; they have also chance to like the others' sharing and they can share these with the others. With that way, individuals have possibility to create a new identity or to transfer their current identities to the others. 
Individuals have chance to to share everything such as the meals they eat, sightseeing places, the clothes they wear, the products they use, etc. in social media. In the sharings, especially it is striking that they people preferred tos hare the luxury products and noteworthy places. They see themselves as privileged upper class by providing personal satisfaction with comments and likes.

In this research, the effect of social media in luxury consumption has been questioned on 208 social media users, contrary to expectations, the effect of social media in luxury consumption has been has been detected as on the low level. It is thought that the income level of respondents is important in this process; because in direct proportion with income level, the consumption level of luxury products increase. $40.4 \%$ the respondents in research are in the range of 1301-3300 TL. It is thought that because of their effort to meet their basic needs, their income level becomes insufficient to meet their luxury expectations. Thus, as a supportive reflection of research, it has been seen that when the income level increased the effect of social media on luxury consumption.

If has been found that the effects of social media on the luxury consumption of participants, who have 5301-7300 TL monthly income, are higher than the the participants, who have lower monthly income.

Another variable of social media, which has been determined as effective on luxury consumption, is the time of spending in a day on social media sites. The group, which has the less effect of social media on luxury consumption, is created by individuals, who spend 30 minutes and less. When the using time of social media increased, the effect of social media on luxury consumption increases, too. Right in this point, it is possible to see that the people, who spend more time in social media, is affected by this environment and they are directed to luxury consumption.

It has been seen on the research that the effect of social media on luxury consumption does not make difference due to individuals' gender, age, educational status and the social media sites they use most. In other words, men and women at different ages, different educational levels and different social media sites in terms of individuals who use social media on luxury consumption shows similar effects.

Research includes the 208 participant social media users, who are more than 18 -year old, to determine the effect of social media on luxury consumption; however the $62.5 \%$ participants are in the age range of 22-31-year old. The purpose of social media use among this age group may be socialization, research, communicate with friends, etc. It is thought that the impacts of social media on luxury consumption in more advanced age; because in the younger ages, it is thought that the efforts of people to be successful in their education lives and to have the expected position in their business live will be more important; on the other hand, the luxury consumption will be more important after this process, which includes a social and financial order in people's lives. That is why the the effects of social media on luxury consumption have stayed in the lower level. There is a need for more social media users to make a generalization in the results of research. On the other hand, research on luxury consumption decisive variables, income level, and social media is spent focusing on these variables in future research on the basis that in the future, more concrete information is available.

\section{REFERENCES}

Aksu S. ve Ercan, M. (2012). Lüks marka iletişiminde sosyal medyaya uyum sağlamak: gucci ve vakko'nun facebook ve twitter kullanımları üzerine bir inceleme. 17. Türkiye İnternet Konferans1, 7-9 Kasım 2012. Anadolu Üniversitesi İletişim Bilimleri Fakültesi Yunus Emre Kampusu, Eskişehir.

Atwal, G. ve A. Williams (2009). "Luxury brand marketing - the experience is everything!", Journal of Brand Management, 16, 338-346. 
Ciornea, R.; Pop, M.D.; Băcilă, M.F. (2012). Segmenting Luxury Market Based On The Type Of The Luxury Consumed Empirical Study On Young Female Luxury Consumers. International Journal of Economic Practices and Theories, 2(3),143-152.

Ilıcak Aydınalp, G.Ş. (2013). Sosyal medyaya halkla ilişkiler perspektifinden eleştirel bir bakış, The Turkish Online Journal of Design, Art and Communication - TOJDAC October 3 (4): 1-11

Kang, Myunghwa and Schuett, Michael A. (2013). Determinants Of Sharing Travel Experiences In Social Media. Journal Of Travel \& Tourism Marketing, 30, 93-107.

Kaplan, Andreas M. And Michael Haenlein (2010), "Users of the World, Unite! The Challenges and Opportunities of Social Media", Business Horizons, 53, pp.59-68.

Kıray, Mübeccel B. (2005). Tüketim Normları Üzerine Karşılaştırmalı Bir Araştırma. İstanbul: Bağlam Yayıncılık.

Korkmaz, İ. (2013). Facebook ve mahremiyet: Görmek ve gözetle(n)mek. Yalova Sosyal Bilimler Dergisi, 3:5, 107-122.

Li, G., G. Li ve Z. Kambele (2012). Luxury fashion brand consumers in china: perceived value, fashion lifestyle, and willingness to pay. Journal of Business Research, 65, 1516-22.

Özkaşıkcı, I. (2012). Sosyal Medya Pazarlama (Ma) yeni Çağda Sosyal Medya Kullanımı ve Performans Ölçümü. İstanbul: Levent Print City.

Perez, M. E., R. Castaño ve C. Quintanilla (2010). Constructing identity through the consumption of counterfeit luxury goods. Qualitative Market Research: An International Journal, 13, 219-35.

Sabah-Kıyan, Ş. (2013). Kimlik ve tüketim ilişkisini tersinden düşünmek: lüks ürünlerin taklitleri ile kimlik oluşturma. Tüketici ve Tüketim Araştırmaları Dergisi, 5 (1): 53-78.

Sabuncuoğlu, A. (2015) Sosyal medyanın bir gösteriş tüketimi mecrası olarak kullanımı.

Sakarya Üniversitesi İletişim Çalışmaları. Editör: Aydın Ziya Özgür Aytekin İşman. Sakarya: Burak Ofset.

Sayımer, İ. (2008). Sanal Ortamda Halkla İlişkiler. İstanbul: Beta Yayınları.

T1ğlı, M. \& Akyazgan, M. (2003). Özellikli (Lüks) Tüketim Ürünlerinde Enderlik Prensibi ve Bir Uygulama. Kocaeli Üniversitesi Sosyal Bilimler Enstitüsü Dergisi,1 (5), 2137.

Tuğrul, Ç., Toprak, A.,Yıldırım A.; Aygül, E.,Binark, M. ve Börekçi, S. (2009). Toplumsal Paylaşım Ağı Facebook: Görülüyorum Öyleyse Varım. İstanbul: Kalkedon.

Zeybek, I. (2013). Lüks ve Markalama Tüketici Davranışlarında Lüks İmgesi. İstanbul: Beta Yayınları.

http://www.dijitalajanslar.com/internet-ve-sosyal-medya-kullanici-istatistikleri-2016/ (06.06.2016).

http://www.istatistikanaliz.com/faktor_analizi.asp (06.06.2016). 